Article

\title{
Transfer of Development Rights and Cultural Heritage Preservation: A Case Study at Athens Historic Triangle, Greece
}

\author{
Dionysia-Georgia Perperidou*(D), Stavroula Siori, Vasileios Doxobolis, Fotini Lampropoulou and Ioannis Katsios \\ Department of Surveying and Geoinformatics Engineering, University of West Attica, Egaleo Park, Ag. \\ Spyridonos Str., 12243 Athens, Greece; tg14072@uniwa.gr (S.S.); tg16015@uniwa.gr (V.D.); \\ tg16037@uniwa.gr (F.L.); iokat@uniwa.gr (I.K.) \\ * Correspondence: dgperper@uniwa.gr
}

Citation: Perperidou, D.-G.; Siori, S.; Doxobolis, V.; Lampropoulou, F.; Katsios, I. Transfer of Development Rights and Cultural Heritage Preservation: A Case Study at Athens Historic Triangle, Greece. Heritage 2021, 4, 4439-4459. https://doi.org/ $10.3390 /$ heritage 4040245

Academic Editor: Martin Koplin

Received: 30 September 2021 Accepted: 18 November 2021 Published: 22 November 2021

Publisher's Note: MDPI stays neutral with regard to jurisdictional claims in published maps and institutional affiliations.

Copyright: (c) 2021 by the authors. Licensee MDPI, Basel, Switzerland. This article is an open access article distributed under the terms and conditions of the Creative Commons Attribution (CC BY) license (https:// creativecommons.org/licenses/by/ $4.0 /)$.

\begin{abstract}
History and the modern world co-exist in Greece's landscape. The urban spaces of Greek cities contain structures from ancient history alongside contemporary constructions, but intense urban development from the 1960s onwards, as in the historic center of Athens, has led to imbalances with respect to cultural heritage protection. The 1975 Greek Constitution defined the preservation and protection of the cultural environment as a constitutional mandate, and severe restrictions on the exploitation of private properties deemed to be of historical or architectural importance were imposed. Property owners were deprived of their property development rights (DRs), whereas the preservation and conservation of protected constructions became costly, resulting in abandoned buildings and a downgraded urban environment. As the debate over cultural heritage protection and urban regeneration is more topical than ever, the recent legal reintroduction of the transfer of development rights (TDRs) provides new opportunities for property exploitation with respect to cultural heritage protection legislation. Herein is presented a methodological framework on the classification and 3D visualization and representation of DRs and TDRs in relation to the cultural heritage protective framework and its implementation in a selected area of Athens' historic center. Legal and technical aspects that affect 3D DRs and TDRs are emphasized as key elements in the successful implementation of the TDR process.
\end{abstract}

Keywords: cultural heritage protection; 3D development rights; 3D transferable development rights; historic center of Athens

\section{Introduction}

The development and expansion of cities results in urban, outer-urban and agricultural land consumption. As it is predicted that by 2050 two-thirds of the world population will live in cities [1], the pressure on cultural heritage will be great [2,3]. Given the continuous development and expansion of urban spaces, the protection, preservation and promotion of cultural heritage is an issue of great significance and importance both for the scientific community and the state/local authorities. The broad debate on cultural heritage protection, preservation and promotion, with respect to private property owners' rights to exploit their properties and preserve their full property development rights (DRs), started in the USA in the late 1960s. This debate was addressed via the transfer of development rights (TDRs). TDR is an innovative and effective process of protecting cultural heritage and preserving private property owners' rights to benefit from full exploitation of their properties that are under protection as archeological sites, monuments or listed buildings.

Regarding Greece, which is well known for its long and rich history, cultural heritage protection, preservation and promotion is a matter of high importance. Today the contemporary landscape and cultural heritage must co-exist, while in densely populated urban areas cultural heritage resources and reserves are under pressure due to urban/residential development. Since 1975, cultural heritage protection, preservation, conservation and promotion has been a constitutional mandate. The Ministry of Culture and Sports is the 
public authority responsible for placing buildings under protection and listing buildings, monuments and archeological sites. The Ministry also imposes strict regulations and restrictions on building activity and overall property exploitation in the interests of cultural heritage protection. A tight legal framework on cultural heritage protection is in force in Greece, depriving private property owners of their constitutional right to full property development rights (DRs). At the same time, the financial cost to the state to obtain sole ownership on protected but privately owned cultural heritage elements via expropriation is often prohibitive, resulting in the abandonment of properties and the degradation of the urban environment, especially in city centers. To protect cultural heritage, a TDR scheme was introduced into the Greek legal framework in 1979, almost at the same time such a scheme was introduced and implemented in the USA. The scheme, known as the Transfer of Building Factor, was repeatedly judged as unconstitutional in respect of urban legislation and property rights protection. In 2017, a TDR scheme was reintroduced into Greece's legislation for the control and protection of the built environment, but for its successful implementation DR and TDR must be defined.

In this paper, a methodological framework on the classification, 3D visualization and 3D representation of DRs and TDRs in respect of cultural heritage protection is presented. Legal and technical aspects that affect 3D DRs and TDRs are emphasized as key elements in the successful implementation of TDRs, and a methodological implementation in a selected area of Athens' historic center, a block within the limits of Athens' historic triangle, is presented.

\section{The TDR Concept}

According to the theory of property ownership, ownership is subject to a set of rights, obligations and constraints, such as the right for use or the constraint of harmful use or the obligation to respect general building codes/laws. The implementation of property rights promises a stable political environment that offers all the necessary legal and technical tools for their definition and preservation [4,5]. Urban sprawl affects property rights, especially in peri-urban and agricultural areas [6-8]. Development rights embody the limits on the extent to which an existing construction on a land parcel or plot can be developed. The official permissibility of developments is foreseen in official and statutory building rules, however, it is restricted due to regulations imposed by various pieces of legislation, on the protection of cultural heritage, the natural environment, etc. DRs are also part of a property/land parcel or plot's "bundle of rights" and could be subjected to voluntary separation for sale or lease [9]. Furthermore, as agricultural land and open space preservation is essential to citizens' well-being, DR purchase is used to preserve farmland [10] or safeguard public open spaces from intense urban development [10-13], and is incorporated in urban planning [12,14].

In respect of cultural heritage protection, DRs and TDRs were originally introduced into the UK legal framework in 1947 [15]. The State was granted the right or ability to purchase DRs for the development of non-profitable properties and in the case of official, administrative and specific restrictions/provisions on listed buildings or monuments.

In the 1960s, in the USA, the landmarks dilemma arose. Preservation of buildings of great historical or architectural importance was considered less profitable compared to urban development, especially in areas with high land values. TDR were then proposed and enacted, correlated to zoning urban developments, so that demolition of buildings and monuments of great historical or architectural importance could be prevented [16]. In 1968 New York City introduced a groundbreaking TDR program, which, though its implementation was initially problematic, was eventually successful $[17,18]$. New York's landmark buildings, such as Broadway theaters or the Lincoln Center, were thereby preserved, as TDR "space bonus provisions-zoning bonus" was adopted as a toll for urban development and the protection of landmarks [19].

The success of New York's TDR program was based on the non-monetary compensation of owners, as they were granted transferable development rights in another urban 
zone, as was the case with New York's Grand Central Terminal [20]. Following New York's success story, TDR and zoning development was proposed as an integrated process to protect historic buildings and landmarks from demolition by fulfilling owners' claims to the right to full exploitation of the land they own [19-22], helping as well to readjust urban planning, especially in densely populated and overdeveloped urban areas. TDR is exploitable by urban planners, advocates, bankers and landowners, and the availability of new and under-development urban areas is important for the successful protection of cultural heritage [23]. TDR is a "smart development" policy and is known for economic resources leverage, ensuring adequate funding for public or municipal urban development programs [24]. It is also an urban planning tool, especially for social housing development programs, and an efficient tool for urban growth monitoring, when combined with urban plans [25], enhancing urban growth and development in a more sustainable way [26-28]. Bonus development provisions linked to TDR acquisition is a success factor for the whole process [29], while public support and social equity are key elements in TDR implementation and the protection, conservation and preservation of buildings of historical or architectural importance [30]. TDR are used for the protection of natural resources and to supplement transnational cooperation for environmental protection or the improvement of housing conditions [24,31-34], hazard management in seaside areas [35], and even to enable land consolidation to preserve non-urban land from intense exploitation [36].

Consequently, the TDR is a mechanism for preserving important cultural, environmental or common-interest goods (e.g., open spaces) and establishing social housing statutory safeguards through the implementation of a technically and legally defined framework on development rights and restrictions. Transferable development rights are incorporated within the context of urban (or spatial) planning by leveraging private funds.

However, there is still a poor understanding of the actual factors that affect the successful implementation of TDRs, as there is a lack of knowledge on the legal or spatial factors that affect TDR adoption, as well as a lack of localized empirical evidence [37]. The question of the actual spatial, legal and temporal definition and the market price determination of TDRs is a hot issue and needs to be addressed [38-43].

\section{Greece's Legal Framework on Cultural Heritage Protection and TDRs}

\subsection{Cultural Heritage Protection and TDR in Greece: 1832-2007}

Cultural heritage protection in Greece began in the early 1820s, during the Greek War of Independence [44]. When the war ended and the new State was formed, the first governor, I. Kapodistrias, established the National Archeological Museum, and in May 1828 he issued an act forbidding all exports of Greece's antiquities. After Kapodistrias' assassination, King Otto was the Head of the State in the early 1830s. King Otto established the Archeological Service in 1833 and as his main focus was the protection and restoration of the Acropolis, he issued the first contemporary law on the protection of antiquities in 1834. By then, Athens' ancient antiquities were hidden beneath houses, streets and Ottoman period constructions. Almost 60 years later, the 1899 Law on Antiquities revised the 1834 legal framework. The Law determined that all antiquities within the (then) Greek territory were to be in and under the state's possession and protection; the State could expropriate private properties, paying the necessary compensation to property owners [45]. The 1899 Law on Antiquities was amended and improved in 1932 [46], and in 1943 the Monuments Restoration Service was established [47], while all neoclassical buildings built after 1830 and artworks were also placed under the state's protection [48]. After the end of WWII and the 1945-1949 Greek civil war, Greece's recovery efforts were focused on city developments and enhancing the construction of private buildings [49], and as a consequence cultural heritage elements were not only under-protected but in some cases demolished.

Greece's 1975 constitution set cultural heritage protection as a constitutional mandate, introducing, for the first time, increased constitutional protection not only on monuments and archeological sites but on the overall cultural environment, including traditional 
settlements and traditional elements [50]. Following the 1975 Constitutional Mandate on cultural heritage protection, the then president of the Hellenic Tourist Organization, Tzanis Tzanetakis, launched a groundbreaking program for the touristic promotion of traditional and historic settlements. The program foresaw the renovation, by public funding, of buildings of great historical and architectural importance, and their reuse by the state as hotels and hostels for a ten-year period. After the end of that period, owners' rights on the full use of their renovated buildings would be reinstated [51]. The traditional settlements of Ia Santorini Island, Mesta Chios Island, Vizitsa and Makrinitsa Pilio Mountain, Fiskardo Kefalonia Island, Bathia Mani Southeast Peloponnese, Theologos Thasos Island, the old city of Xanthi in northern Greece and Zagorochoria Epeirous were selected for the pilot program that was successful and influenced their overall development [51]. In 1977, the protection of historic/traditional settlements and city centers of great historical, architectural, urban and aesthetic importance was enacted [52]. A series of historic or traditional settlements, historic or traditional city centers and city centers of great architectural importance were put under the strict protection of the State. All construction activities, within the boundaries of the protected areas, are immensely regulated and restricted. The 2003 Law on Antiquities and Cultural Heritage protection revised the overall fragmented legal framework in accordance with Greece's 1975 Constitution provisions [53].

This explicit and full protection of antiquities and cultural heritage in general by the state, with the consequent enforcement of strict rules on construction activities and the use of listed buildings, limited private ownership rights. Owners are deprived of their rights on full property exploitation, e.g., the demolition of listed buildings being banned or strict control by the State being imposed on any restoration, conservation or construction activities. This overprotective legal framework on cultural heritage protection resulted in restrictions on building factor exploitation, especially in city centers, like Athens'. The owner of a three-story listed building that is located in an area where building regulations permit the construction of six-story buildings loses his or her DR to build and exploit the additional three floors. However, according to the Greek Constitution, any restriction imposed by the state on the full use and exploitation of private property is equivalent to expropriation and compensation is due to the property owner.

As it is costly and almost impossible for the Greek state to compensate all owners whose properties are located in areas of firm regulation on cultural heritage protection, an innovative legal framework for the transfer of development rights was introduced in the late 1970s. Law 880/1979 enacted the TDR framework, almost simultaneously with the USA TDR legislation. A listed building owner or property owner within a declared archeological area site, deprived of the right to full property use and building activity, was granted the right to "transfer" the non-exploitable but legitimate existing building factor to a property located at another part of the city or even outside the city's boundaries. This process is known as "Transfer of Building Factor" [54]. The owner of transferable DR (of the non-exploitable building factor) was granted the an official executable deed, by the State, with details on the transfer process, e.g., total transfer surface, the building to which the transferable DR applies, etc., by presidential decree. Thus, the owner gained access to financial resources, which in the case of listed buildings could only and exclusively be used for their restoration. This Law was judged unconstitutional by the Council of State, as no zones for transferable building factors were officially and by presidential decree declared, whereas the transfer of a DR to a sole recipient building in one other area added an additional burden to its neighboring ones [55,56].

In 1995 Law 2300 was enacted providing the legal and technical basis for the determination of recipient building factor zones, as well as technical details on the transfer process [57]. This Law was also judged unconstitutional by the Council of State, because of the provision that all urban areas be considered as a single recipient building factor zone was found not to be acceptable. The Court also ruled that before the transfer process, detailed urban plans on recipient zones for each distinct municipality had to be enacted by presidential decree [58-60]. In 2002 Law 3044 was enacted, aiming to deal with the 
legal limbo of precedent legislation that was judged unconstitutional, and also included provisions for non-exploitable private properties after the implementation of official urban plans [61]. Law 3044 was judged partially unconstitutional, as the Court's previous remarks on recipient zones were not taken into consideration. However, as owners were deprived of their rights to full property exploitation, due to statutory restrictions, they had the right to ask for transfer of their DR. Consequently, the Council ruled suspension of transfer deeds issued, as those deeds could not be of any use or value prior to the determination of recipient zones [62].

The non-implementation of TDR legislation deprived the owners of listed buildings access to adequate financial resources for the preservation, renovation and promotion of their properties as cultural heritage elements. In parallel, the Greek state could not compensate the owners of properties that were located within the boundaries of archeological sites. Eventually, the majority of listed buildings could not be restored, renovated and reused and were subjected to wear and tear, while declared archeological sites could not be officially restored and made accessible to the public. As a result, the abandonment of historical buildings is the main cause of the downgraded urban and built-up environment, while important aspects of historical memory are lost due to the neglect of cultural heritage.

\subsection{Current Legal Framework on TDRs and Cultural Herritage Protection in Greece}

Ten years after the latest Council of State Decision on Transfer of Development Rights, Law 4495 was enacted and then amended by Law 4759 in 2020 [63,64]. The new legislative and regulatory framework introduces all the legal and technical provisions for TDRs in respect of Council of State judgments and rulings from 1993 to 2007. The new framework combines cultural heritage protection with legislation on illegal constructions or buildings legalization process, defining:

- Legal and technical provisions on transfer receiving zones, zones of excess illegal constructions/buildings, officially declared for each municipality and by presidential decree;

- The Municipality Digital Urban Identity, an open-access official spatial database, where all relevant data on urban and spatial plans and building regulations are maintained and updated by each municipality;

- The Digital Land Bank, an open-access database for the issue, management, and exploitation of TDR Deeds, under the supervision of the Ministry for the Environment and Energy;

- The object of TDR is the transfer of building factor, abstracted from a building or property and superinduced to a recipient building or property;

- The TDR deed corresponds to the surface (in square meters) that is not allowed to be built on due to official administrative acts that limit construction and property exploitation. The transfer deed is exploitable for buildings/properties within the same municipality or a neighboring municipality or the same prefecture that has valid urban plans and valid transfer recipient zones. Recipient buildings fall into two categories: (i) buildings that exceed official (licensed or not) building regulations and (ii) buildings located within urban zones/areas of special construction/reconstruction.

This new legal framework also corresponds to Transfer of Building Factor, as the whole transfer process is based solemnly on building surfaces that cannot be built on or are not exploitable. However, the owner's deprivation of the right to full property exploitation is not limited to buildable surfaces. Parameters such as a property's spatial location, land use, view of important POIs, or the natural landscape, the location of neighboring properties, etc., must also be taken into consideration along with the 3D development of properties and building volumes.

The research presented herein is focused on the identification and definition of 3D DRs and TDRs in the interest of preserving cultural heritage while respecing property owners' property development rights, especially in the case of listed buildings. The presented 
methodology is implemented in a block located in Athens' historical center, specifically in the historical triangle area.

\section{Materials and Methods}

In Greece's densely populated cities and urban areas, cultural heritage elements and resources are usually located in private properties. The protective legal framework applying to cultural heritage deprives private property owners of their rights to full use and development of their properties. Especially in the case of listed buildings, current legislation foresees cost-prohibitive restoration and renovation works, so that owners come to consider their properties a burden. Thus, they are not willing or able to take any action for restoration and preservation, which results in buildings suffering neglect and consequent degradation of the urban environment. However, if property owners are fairly compensated for being deprived of their right to full property use and exploitation and given adequate financial resources and funds to restore and renovate their buildings, urban degradation could be reversed. Eventually, property owners will not consider their properties as costly burdens subjected to numerous restrictions but instead will become essential players in the urban regeneration process through cultural heritage protection, preservation and promotion.

To identify TDRs of private properties that are under the strict legal framework on cultural heritage protection, the study area must first be defined. Properties' statuses must be examined with respect to current (or/and past) urban planning regulatory frameworks, so that the actual and 3D DRs are defined. Next, restrictions and regulations imposed for cultural heritage protection correlated to 3D Development Rights will define restrictions under 3D DRs and determine the 3D TDRs (see Figure 1).

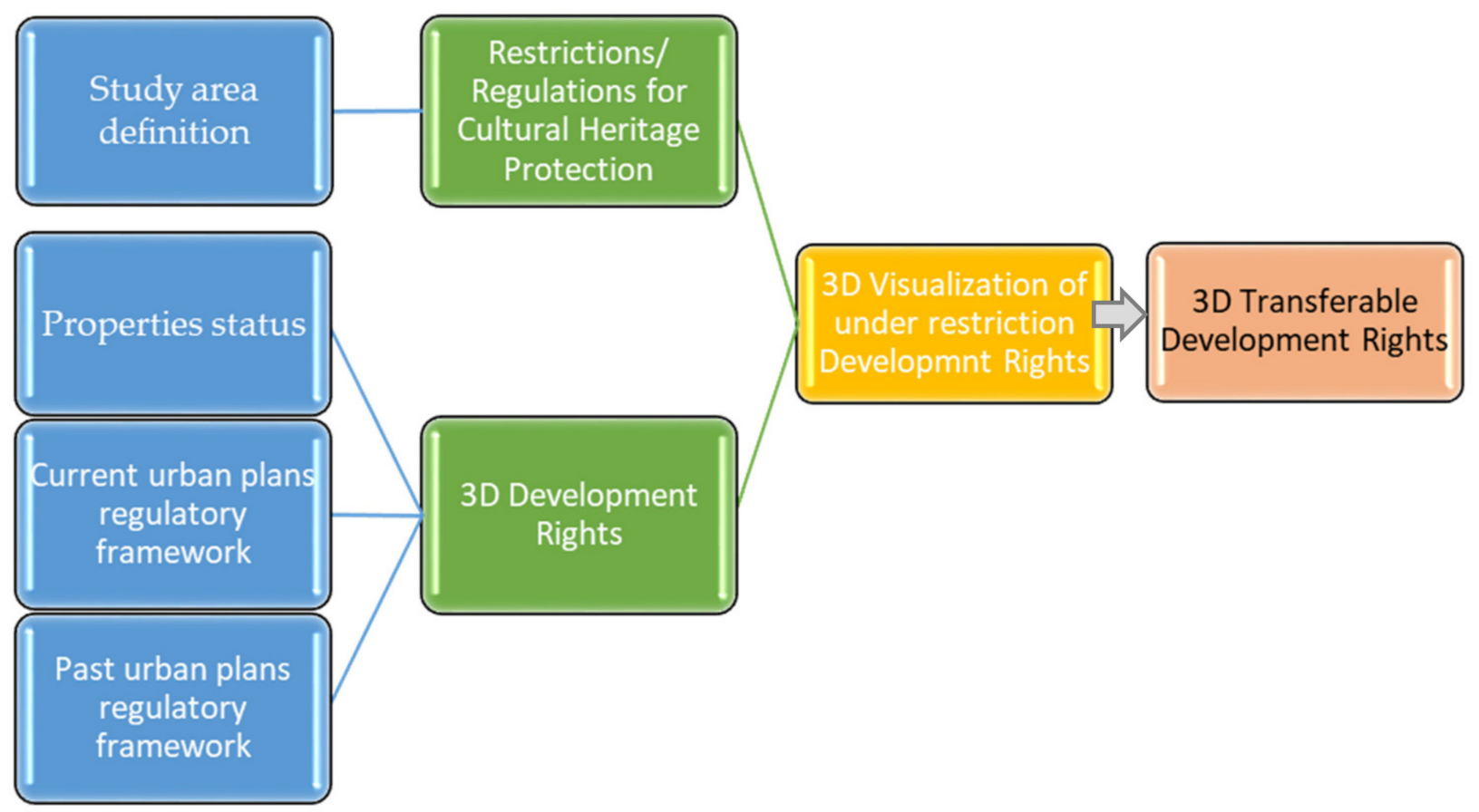

Figure 1. Methodological steps.

The definition of the study area is important so as to:

a. Identify the regulatory / protective legal framework on cultural heritage protection and especially the 3D restrictions on urban development for cultural heritage protection.

b. Identify the current status (i) of property ownership and (ii) urban planning regulations. 
c. Identify the development of buildings that are incompatible with current urban planning regulations with respect to the regulatory framework on urban development during the period of their construction licensing and construction development.

By identifying the property status, the current urban planning regulations and the regulatory urban planning framework of already developed buildings, the spatial and temporal identification and diversification of 3D DRs is feasible. Comparing the 3D DRs to the $3 \mathrm{D}$ restrictions for cultural heritage protection, the transferable 3D DRs can also be defined.

\subsection{Identification of Data Sets}

Property development is three-dimensional, originally over the ground but in the last few decades under the ground as well [65] and is subjected to various 3D legally-described regulations, restrictions [66-68] or 3D development conditions in the real world [69]. Official technical documentation, construction licensing and relevant administrative regulations on properties is two-dimensional [68]. The definition and spatiotemporal representation of 3D development rights for private properties subjected to legal-technical restrictions due to cultural heritage protection prerequisite the identification of 3D property rights, restrictions and rules (RRR), as those derive from official and public archives, concerning:

- Property rights per se;

- Urban development regulatory frameworks, current and precedent, and the official licensing of stand-alone buildings;

- Official declarations of regulatory frameworks for cultural heritage protection, standalone listed buildings and places/settlements/city centers of great historic, traditional or architectural importance;

- Urban landscape spatiotemporal documentation via official aerial photos and stereopair.

Figure 2 presents the official data sources on properties' RRRs, and Table 1 presents the definition and classification of the relevant data sets and their general spatial and descriptive attributes.

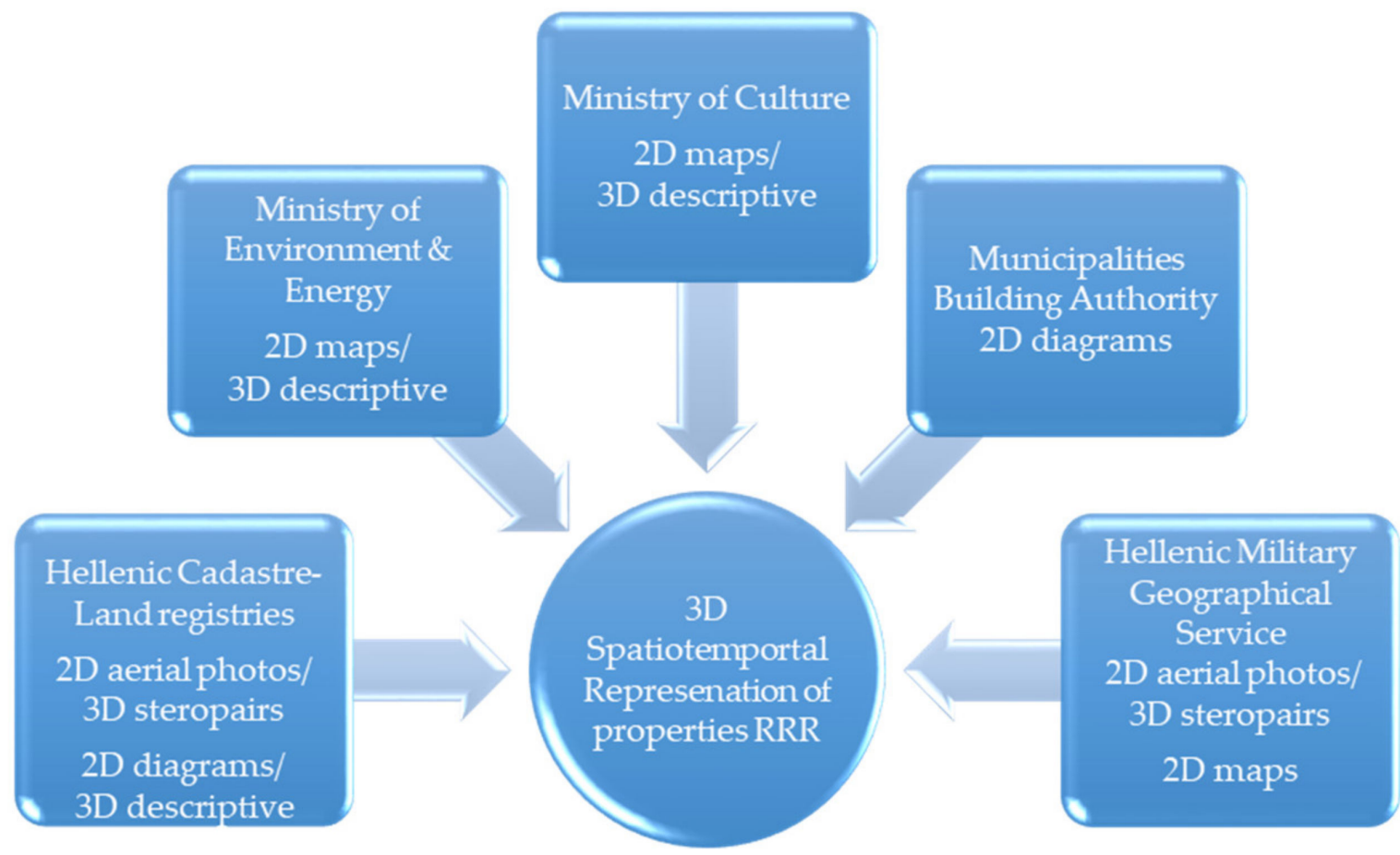

Figure 2. Public authorities data on property rights, regulations and cultural heritage protection restrictions. 
Table 1. DR Data sets definition and attributes.

\begin{tabular}{|c|c|c|c|}
\hline Data Set Authority & Data Set Description & Data Set Spatial Information & $\begin{array}{l}\text { Data Set Descriptive } \\
\text { Information }\end{array}$ \\
\hline $\begin{array}{l}\text { Hellenic Cadastre/ } \\
\text { Land Registries }\end{array}$ & $\begin{array}{c}\text { Deeds on land parcels/ } \\
\text { land parcel geometrical } \\
\text { description }\end{array}$ & $\begin{array}{l}\text { 2D topographic diagrams and } \\
\text { 2D cadastral diagrams, } \\
\text { scale 1:500, 1:1000-1:2000 }\end{array}$ & $\begin{array}{l}\text { Deeds with information on } \\
\text { owners, property rights and } \\
\text { deed transcription details }\end{array}$ \\
\hline Hellenic Cadastre & $\begin{array}{l}\text { Historic aerial photos } \\
\text { andorthophotomaps }\end{array}$ & $\begin{array}{c}\text { Printed or scanned or digital } \\
\text { 2D aerial/satellite photos/ } \\
\text { 3D stereopair }\end{array}$ & - \\
\hline \multicolumn{4}{|l|}{ Ministry of Culture } \\
\hline $\begin{array}{l}\text { Listed Buildings } \\
\text { Department }\end{array}$ & $\begin{array}{l}\text { Listed Buildings } \\
\text { Declaration }\end{array}$ & $\begin{array}{c}\text { 2D set of detailed and } \\
\text { approved: topographic } \\
\text { diagrams, scale } \\
\text { 1:200/500/1000 } \\
\text { top views, sections etc., scale } \\
\text { 1:100, 1:200, 1: } 500\end{array}$ & $\begin{array}{c}\text { Declaration by presidential } \\
\text { decree } \\
\text { Protection status/regulations } \\
\text { and restrictions } \\
\text { Owners }\end{array}$ \\
\hline \multirow[t]{2}{*}{$\begin{array}{l}\text { General Directorate of } \\
\text { Antiquities \& } \\
\text { Cultural Heritage }\end{array}$} & $\begin{array}{l}\text { Archeological Sites } \\
\text { Declaration }\end{array}$ & 2D maps, 1:2000, 1:5000 & $\begin{array}{c}\text { Declaration by presidential } \\
\text { decree } \\
\text { Protection status/regulations } \\
\text { and restrictions }\end{array}$ \\
\hline & $\begin{array}{l}\text { National Archive on } \\
\text { Monuments }\end{array}$ & $\begin{array}{l}\text { Archeological cadastre, } \\
\text { web GIS }\end{array}$ & $\begin{array}{l}\text { Greek Heritage List, } \\
\text { web database }\end{array}$ \\
\hline \multicolumn{4}{|l|}{$\begin{array}{l}\text { Ministry of Environment \& } \\
\text { Energy }\end{array}$} \\
\hline $\begin{array}{l}\text { Spatial Planning } \\
\text { General Directorate }\end{array}$ & $\begin{array}{l}\text { General Archive on } \\
\text { Spatial Planning }\end{array}$ & $\begin{array}{l}\text { 2D maps/diagrams on } \\
\text { land use zones, } \\
\text { scale: 1:5000 or less }\end{array}$ & $\begin{array}{c}\text { Official approval decision by } \\
\text { presidential decree or } \\
\text { ministerial decision }\end{array}$ \\
\hline $\begin{array}{l}\text { Urban Planning } \\
\text { General Directorate }\end{array}$ & $\begin{array}{l}\text { Urban Planning } \\
\text { Archive/e-poleodomia }\end{array}$ & $\begin{array}{l}\text { 2D detailed maps on urban } \\
\text { plans, urban zones, scale 1:500, } \\
1: 1000,1: 2000\end{array}$ & $\begin{array}{c}\text { Presidential decree on } \\
\text { building regulations and } \\
\text { restrictions, } \\
\text { Specifications on land uses }\end{array}$ \\
\hline $\begin{array}{l}\text { Urban Planning } \\
\text { Directorate }\end{array}$ & $\begin{array}{c}\text { Traditional Settlements } \\
\text { Archive }\end{array}$ & $\begin{array}{c}\text { 2D maps / diagrams prior } \\
\text { to the } 1923 \text { settlements } \\
\text { boundaries, scale 1:2000, } \\
1: 5000\end{array}$ & $\begin{array}{c}\text { Presidential decree or } \\
\text { regional authority decision on } \\
\text { boundaries description, } \\
\text { building regulations and } \\
\text { restrictions } \\
\text { Specifications on land uses }\end{array}$ \\
\hline $\begin{array}{l}\text { Urban Planning } \\
\text { Directorate }\end{array}$ & Listed Buildings Archive & $\begin{array}{l}\text { 2D set of detailed and } \\
\text { approved: topographic } \\
\text { diagrams, scale } \\
\text { 1:200/500/1000 } \\
\text { top views, sections, etc., } \\
\text { scale } 1: 100,1: 200,1: 500\end{array}$ & $\begin{array}{c}\text { Declaration by presidential } \\
\text { decree } \\
\text { Protection status/regulation } \\
\text { and restrictions } \\
\text { Owners }\end{array}$ \\
\hline $\begin{array}{l}\text { Municipalities } \\
\text { Building Authority }\end{array}$ & $\begin{array}{l}\text { Official Approved } \\
\text { Building Permits Archive }\end{array}$ & $\begin{array}{l}\text { 2D set of detailed and } \\
\text { approved: topographic } \\
\text { diagram, scale } \\
\text { 1:200/500/1000 } \\
\text { top views, sections etc., } \\
\text { scale } 1: 100,1: 200,1: 500\end{array}$ & - \\
\hline \multirow[t]{2}{*}{$\begin{array}{c}\text { Hellenic Military } \\
\text { Geographical Service }\end{array}$} & $\begin{array}{l}\text { Historic and current } \\
\text { aerial photos }\end{array}$ & $\begin{array}{l}\text { Printed or Sand or Digital 2D/ } \\
\text { 3D stereopair }\end{array}$ & - \\
\hline & Historic and current maps & 2D 1:5000/1:50000 & \\
\hline
\end{tabular}




\subsection{D Definition of Properties Development Rights \& Restrictions}

\subsubsection{Data on Land Parcels}

Two-dimensional spatial attributes on land parcels are described in legal documents and deeds registered to land registries and after 1995 to the Hellenic Cadastre spatial and descriptive database [70]. Hellenic Cadastre is operative in some parts of Greece and under development in others, but definitive or temporal spatial data on cadastral parcels are available on the web (Figure 3). Two-dimensional spatial data on cadastral parcels are correlated with official historical aerial photos or orthophotomaps also available from the Hellenic Cadastre (Athens Greece) or the Hellenic Military Geographical Service (Athens Greece), so as to identify the spatial evolution of the built environment (Figure 3). The definition and description of property rights, e.g., ownership, easement, etc., that are exercised on land parcels/plots or constructions are also included in deeds, either registered to land registries or to official Cadastral Offices, all over Greece operated by the Hellenic Cadastre.

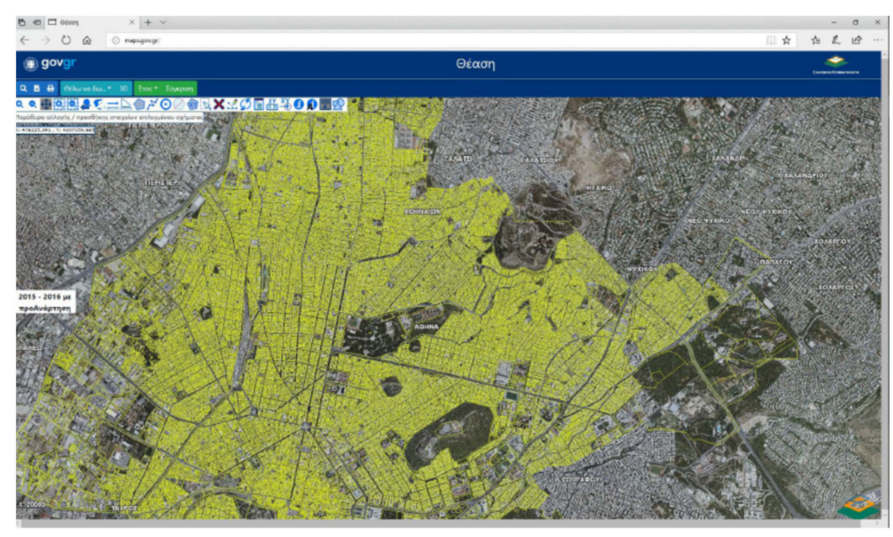

(a)

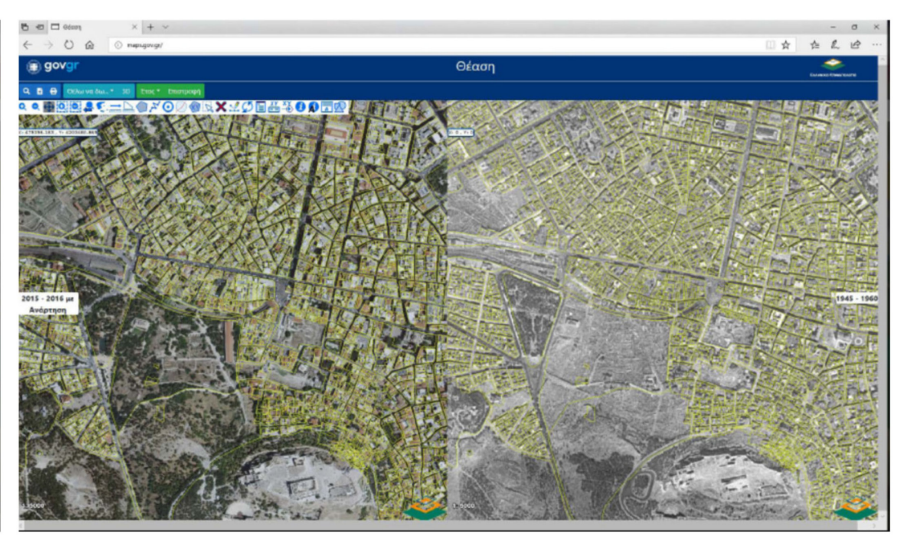

(b)

Figure 3. (a) Hellenic Cadastre land parcels' spatial features. (b) Parcels' spatial features on the 2007-2009 orthophotomap (left) and the 1945 historic othophotomap, Athens Municipality, temporal cadastral data for Hellenic Cadastre development. (Source: maps.gov.gr, accessed on 29 September 2021).

\subsubsection{Data on Urban Development, the Urban Environment and the Built Environment}

The regulatory framework on urban development, urban planning and building regulations can be retrieved from the official web-GIS on urban planning, e-poleodomia, maintained by the Ministry of Environment and Energy. The E-poleodomia web-GIS (http://gis.epoleodomia.gov.gr/v11/index.html, accessed on 22 September 2021) provides detailed data sets of scanned urban plans and their official approval by presidential decree (Figure 4). In case of the non-availability of scanned urban plans from e-poleodomia, the equivalent hard copy is available in the Ministry's official analogical archive. Urban plans are georeferenced using the official Greek Coordinates System (GGRS87/EPSG2 2100) and official aerial photos or orthophotomaps.

Data on spatial planning are available from the Directorate on Spatial Planning, Ministry of the Environment and Energy in hard copy. Data on official building permits are available, also in hard copy, from the responsible department of the Municipal Building Authorities. Finally, field research is necessary to collect data on current conditions of the urban and built environment, e.g., construction characteristics, number of building floors, building condition, building use(s), etc., and public space characteristics (geometry, condition, etc.). 


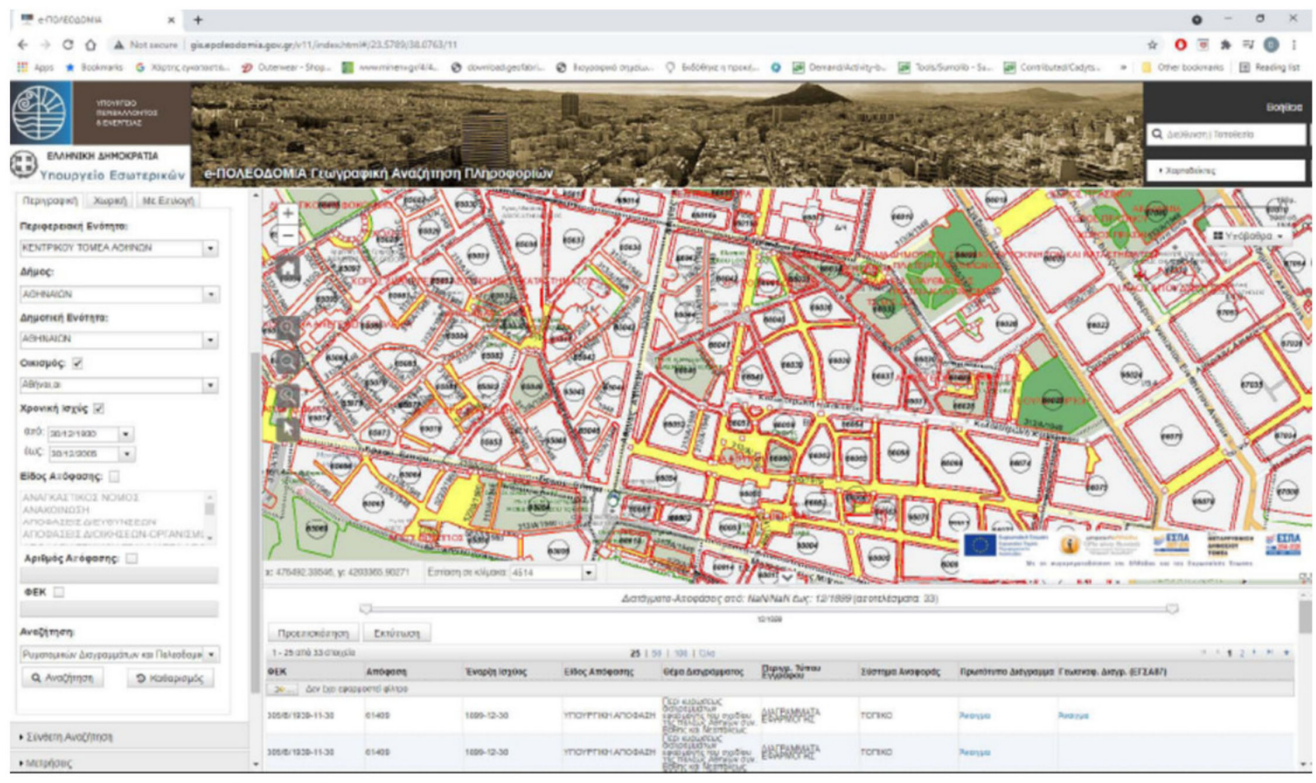

Figure 4. E-poleodomia web-GIS, web database on urban plans. (Source: gis.epoleodomia.gov.gr, accessed on 29 September 2021).

\subsubsection{Data on Cultural Heritage}

Data on protected cultural heritage elements, declared archeological sites, monuments and listed buildings are kept by the Ministry of Culture. The Ministry of the Environment keeps official records on settlements, city centers, listed buildings, etc., declared to be of historical, traditional or great architectural or natural importance. Relevant data on sites, monuments or building types can be retrieved via the Archeological Cadastre Web-GIS (https: / / www.arxaiologikoktimatologio.gov.gr/, accessed on 22 September 2021) and the Greek Cultural Heritage List (Figure 5).

As for listed buildings, detailed drawings, e.g., topographic diagrams, top views, etc., are available only in hard copy at the official Listed Buildings Archive, Ministry of Culture (http:/ /listedmonuments.culture.gr/search_declarations.php, accessed on 22 September 2021) or the Listed Building Archive, Ministry of the Environment (http:/ / estia.minenv.gr/, accessed on 22 September 2021). Data on construction restrictions for cultural heritage protection that affect urban planning and plans, e.g., zones' boundaries, building factors diversification, etc., are available from the Ministry of Environment in hard copy.

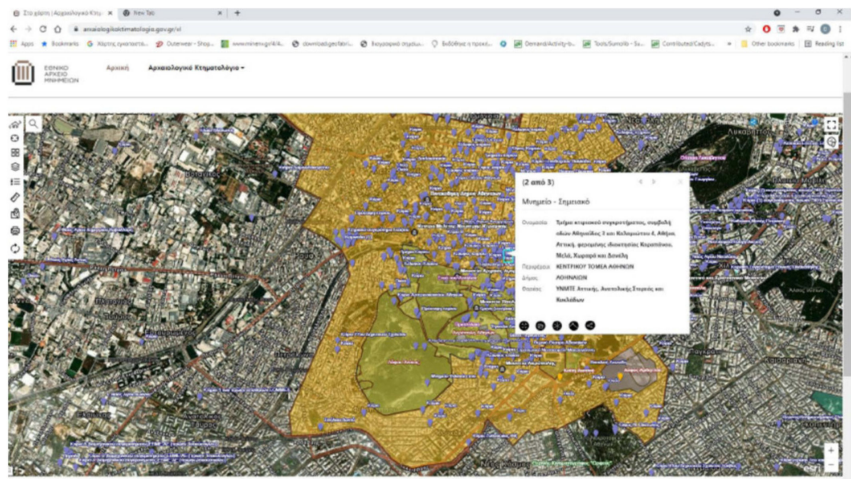

(a)

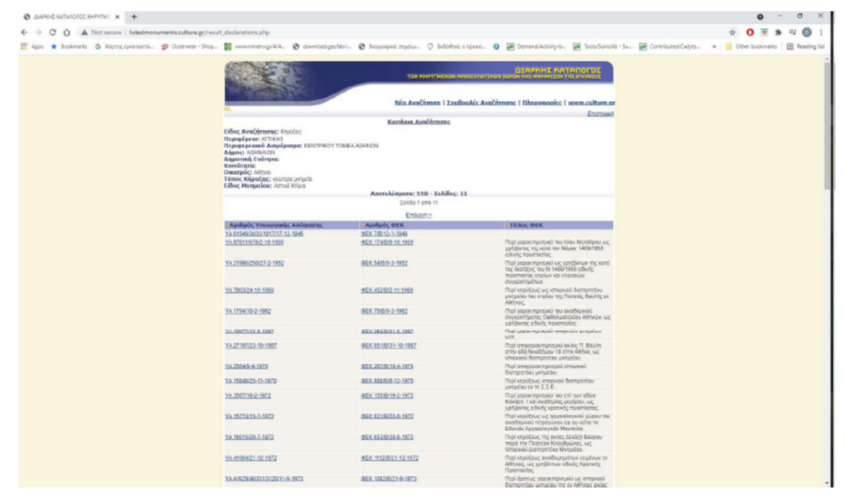

(b)

Figure 5. (a) Archeological Cadastre. (b) Greek Cultural Heritage List. (Source: Ministry of Culture). 


\subsection{Determination of 3D DRs and TDRs}

The correlation between properties' 2D spatial characteristics and types of property rights relating to building regulations and three-dimensional real-world construction and development defines valid 3D DRs. Three-dimensional TDR classification derives from 3Dvalid DRs correlated with restrictions concerning cultural heritage protection, e.g., vertical development limitations, built surface limitations, expropriation (partial or full). Both 3D DRs and TDRs are legally and technically described in legal documents. Deeds, current or previous legislation, presidential decrees or ministerial decisions on urban development and cultural heritage protection refer to (a) actual horizontal and vertical, usually over the ground development on plots or land parcels and to $(b)$ actual horizontal and vertical legal and technical restrictions on elements of cultural heritage protection, identifying three categories of built-volume (actual or virtual) in urban environments:

- 3D actual constructed built-volume, fragmented to floors;

- 3D virtual development rights with respect to built-volume, fragmented to floors;

- 3D Transferable Development Rights with respect to built-volume, fragmented to floors.

Based on prior research [71], the 3D transferable development rights are further categorized and are presented in Table 2. The built-volumes' 3D representation and visualization is achieved with 3D Sketch-up software (2021, free access) and is presented in the next section.

Table 2. Classification of 3D DRs and TDRs.

\begin{tabular}{|c|c|c|c|}
\hline $\begin{array}{c}\text { Cultural Heritage Protection } \\
\text { Restrictions }\end{array}$ & Property Status & $\begin{array}{c}\text { Restricted 3D Development } \\
\text { Rights }\end{array}$ & $\begin{array}{c}\text { 3D Transferable } \\
\text { Development Rights }\end{array}$ \\
\hline \multirow{4}{*}{ Archeological Site Declaration } & $\begin{array}{c}\text { Built land parcel (legally)/fully in } \\
\text { declaration area }\end{array}$ & Full property expropriation & $\begin{array}{l}\text { 3D building total volume } \\
\text { fragmented to floors }\end{array}$ \\
\hline & $\begin{array}{l}\text { Built land parcel (legally)/partial } \\
\text { in declaration area }\end{array}$ & $\begin{array}{c}\text { Land parcel partition due } \\
\text { declaration/partial property } \\
\text { expropriation } \\
\text { and remaining } \\
\text { non-exploitable building factor }\end{array}$ & $\begin{array}{l}\text { 3D building partial volume due to } \\
\text { land parcel partition }\end{array}$ \\
\hline & $\begin{array}{l}\text { Unbuilt land parcel/fully in } \\
\text { declaration area }\end{array}$ & $\begin{array}{l}\text { Full property expropriation, } \\
\text { including fully non-exploitable } \\
\text { official building factor }\end{array}$ & $\begin{array}{l}\text { 3D building total volume } \\
\text { fragmented to floors (visualized) }\end{array}$ \\
\hline & $\begin{array}{c}\text { Unbuilt land parcel/partial in } \\
\text { declaration area }\end{array}$ & $\begin{array}{c}\text { Land parcel partition due } \\
\text { declaration/partial property } \\
\text { expropriation and } \\
\text { non-exploitable remaining } \\
\text { building factor }\end{array}$ & $\begin{array}{l}\text { 3D building partial volume due to } \\
\text { land parcel partition }\end{array}$ \\
\hline \multirow[b]{2}{*}{ Listed-building } & $\begin{array}{l}\text { Listed-building/no permissible } \\
\text { further construction } \\
\text { Listed-building/permissible }\end{array}$ & $\begin{array}{l}\text { Non-exploitable remaining } \\
\text { building factor }\end{array}$ & $\begin{array}{l}\text { 3D building partial volume } \\
\text { fragmented to upper floors }\end{array}$ \\
\hline & $\begin{array}{l}\text { further construction/restrictions } \\
\text { due to building regulations (e.g., } \\
\text { building land parcel coverage) }\end{array}$ & $\begin{array}{l}\text { Non-exploitable remaining } \\
\text { building factor }\end{array}$ & $\begin{array}{l}\text { 3D building partial volume } \\
\text { fragmented to upper floors }\end{array}$ \\
\hline \multirow[b]{2}{*}{$\begin{array}{l}\text { Under cultural protection } \\
\text { legislation urban area }\end{array}$} & $\begin{array}{l}\text { No listed building/further } \\
\text { construction development } \\
\text { restrictions }\end{array}$ & $\begin{array}{l}\text { Non-exploitable remaining } \\
\text { building factor }\end{array}$ & $\begin{array}{l}\text { 3D building partial volume } \\
\text { fragmented to upper floors }\end{array}$ \\
\hline & $\begin{array}{l}\text { No listed building over } \\
\text { constructed due to precedent } \\
\text { building regulation, before } \\
\text { cultural protection restrictions } \\
\text { enforcement }\end{array}$ & $\begin{array}{l}\text { Floor expropriations for cultural } \\
\text { heritage promotion }\end{array}$ & $\begin{array}{l}\text { 3D building partial volume } \\
\text { fragmented to upper floors }\end{array}$ \\
\hline
\end{tabular}

\section{Case Study}

Athens' historical triangle, part of Athens' historic center, is one of the world's oldest and still livable city centers, with over 3000 years of history, where monuments, like the Acropolis, and history co-exist with the modern world. Modern Athens' urban development began in the early 1830s, when King Otto declared Athens as the Capital of the newly formed Greek State. The King assigned the architects Stamatis Kleanthis and Eduard Schaubert to the preparation of the official City Development Plan, approved in 1833 and 
then revised, in 1834, by the architect Leo von Klenze. The Plan foresaw that the new urban formation would be developed around the then existing old small town located underneath the north side of Acropolis Hill. The Plan's key feature is the triangular shape of the new urban development, formed by the newly created three "principal streets" that connect the main three new public spaces. By the 1880s the three principle streets and two of the triangle's three public spaces were developed, existing cultural heritage elements, such as byzantine churches, were preserved, and new open public spaces were created (Figure 6).

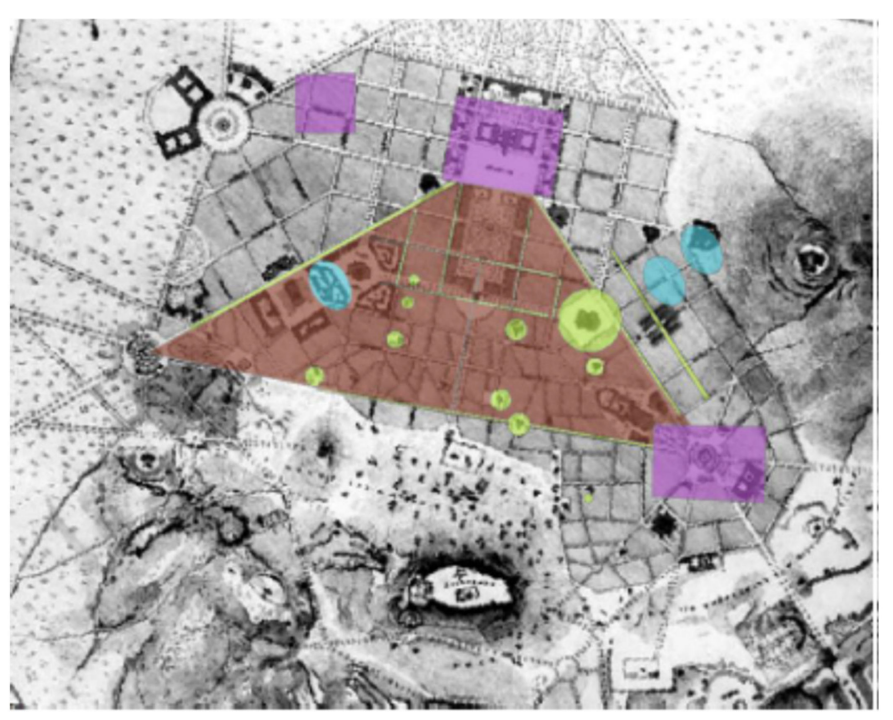

(a)

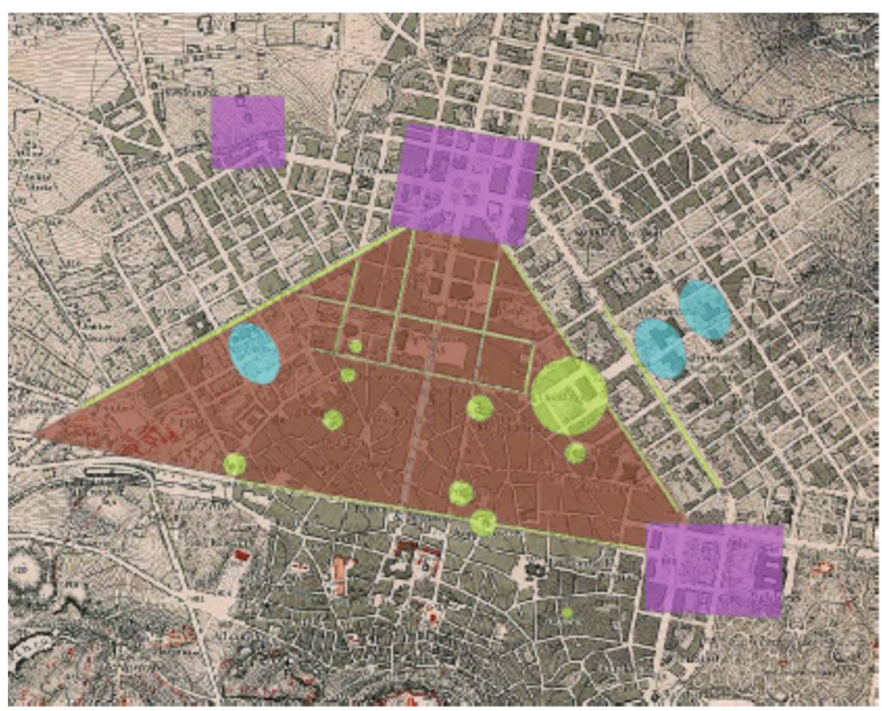

(b)

Figure 6. (a) Athens' historic triangle development, 1833 Kleanthis-Schaubert plan. (b) The 1884 existing urban development depicted on Kaupert maps. Brown: historic triangle; Yellow: new road network (as built) and existing cultural heritage; Purple: public spaces set out in the 1833 plan, implemented with revisions; Blue: new public spaces.

By the end of 1920s the old small town of the 1830s had been transformed into a modern European city and the "Triangle" was the administrative, economic and social center of Greece's capital. Contemporary public buildings with great architecture, such as the old palace, the old parliament, the old Athens university, and two- to four-story elegant private buildings, e.g., private houses, hotels, restaurants, etc., co-existed with monuments dated to the ancient world, the Byzantine and the Ottoman era [72]. In the early 1950s Greece had to cope with the social and economic decline following WWII and the consequent civil war. Athens' reconstruction was prioritized as a path to Greece's overall economic and social recovery, however, no provisions for cultural heritage protection were in force and each owner had the right to use and exploit their property as they wished. From 1950 to the late 1970s, many of the "Triangle's" old and elegant private houses were demolished and replaced by seven- or eight-story buildings that were used for commerce, small industries and public or private administration.

In 1979, and after the enactment of Greece's 1975 Constitution, Athens' city center was characterized as historic/traditional by presidential decree and was placed under the protection of the Archeological Service (Figure 7). All new building permits ought to have Archeological Service approval. The Archeological Service was also given the authority to recommend for preservation buildings with elements of traditional architecture and to institute regulations or restrictions so as to preserve the traditional character of the buildings under protection in Athens' central urban area. Simultaneously, many buildings of great architectural or historical importance were declared as listed buildings either by the Ministry of Culture or the then Ministry of Urban Development. 


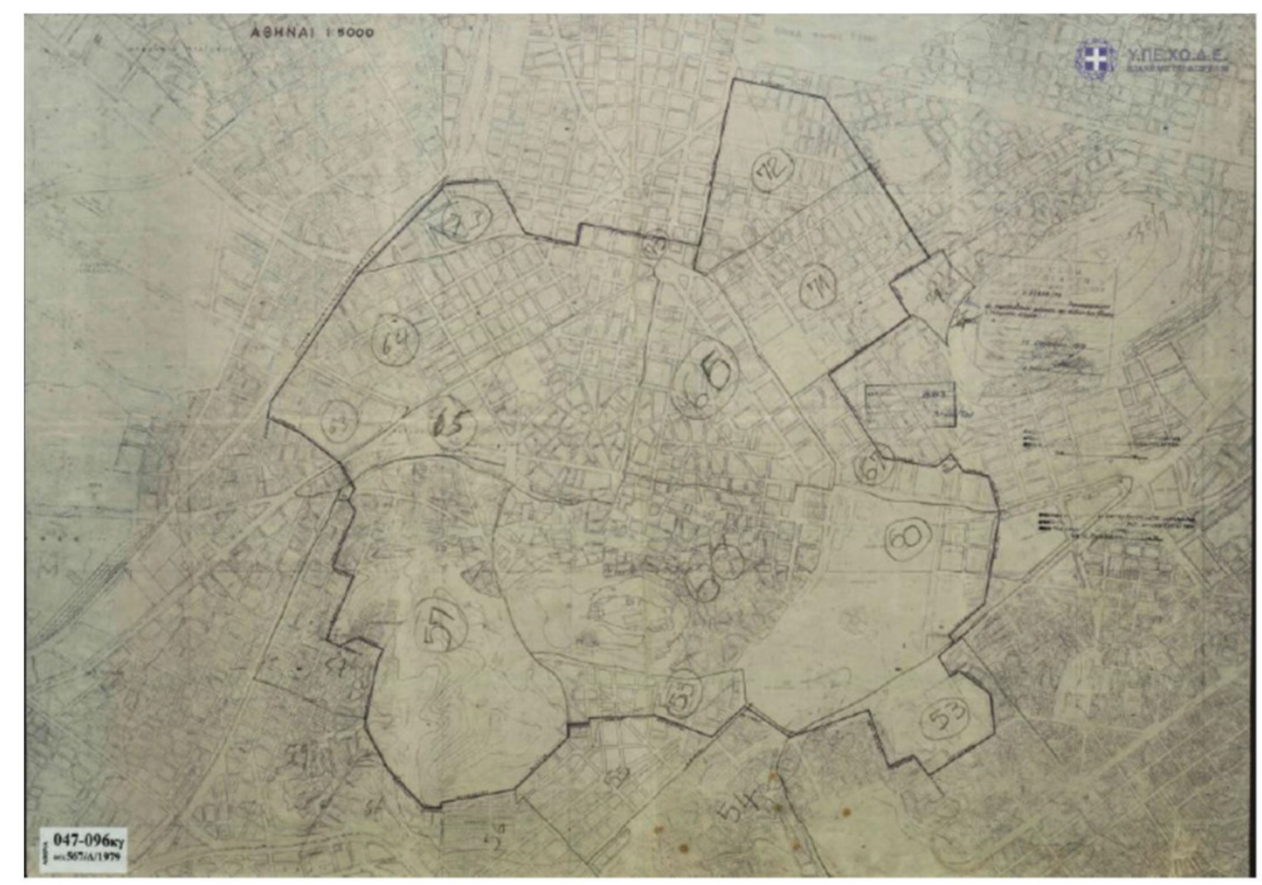

Figure 7. 1979 map of Athens' city center that is characterized as traditional. (Source: Ministry of the Environment \& Energy urban plan archive).

Today, Athens' historical triangle is part of the wider Historic and Commercial Athens Center and one of the most protected areas in terms of cultural heritage preservation and promotion. It is also one of the most attractive parts of the city as, besides its proximity to the Acropolis archeological area, it is the epicenter of cultural, recreational and commercial activities for tourists and Athenians. Within its boundaries, multistory modern buildings co-exist with monuments and listed buildings that in some cases are worn and abandoned. This multidimensional aspect of the Athens historic triangle affects private property management and exploitation. Thus, the necessity for definition and assessment of 3D DRs and TDRs is urgent in order to satisfy owners' complaints at not having full use of their properties, and for the preservation of the historic triangle's traditional and historical characteristics.

\section{Methodology Implementation}

The methodology is implemented in the historic triangle, Athens Municipality, block no. 65027, which is located within the boundaries of the 1833 Kleanthis-Schaubert city plan and in the center boundary of the City of Athens that was declared as historic/traditional in 1979. The block no. 65027 is delimited by Evripidou, Epikourou, Evmorfopoulou and Sachtouris streets, and consists of nine plots with buildings developed in various time periods (Figure 8).

The selected block is also included in the 1948 Athens urban plan revision (Figure 9), and the current regulatory framework on building rules and cultural heritage protection restrictions, enacted in 1998 foresees a maximum building factor of 2.0 that corresponds to a maximum building height of $22.75 \mathrm{~m}$ in respect of the Building Code, restricted to $11 \mathrm{~m}$ for cultural heritage protection. Permitted land uses are mixed residential with recreational, cultural and commercial uses, and Archeological Service approval is obligatory before any intervention in the built environment or the issue of any new building permit.

Building characteristics (e.g., constructed building factor, number of floors, etc.), their actual structural condition with respect to conservation and restoration processes and their status regarding cultural heritage protection derived from (a) field surveys, (b) listed buildings archives' on the spot surveys (Ministry of Culture and Ministry of Environment and Energy) and (c) the Athens Municipality Building Authority's on the spot surveys, conducted between October 2019 and March 2020, are presented in Table 3. Constructed 
building factor calculations are derived from the total building surface divided according to each plot's surface.

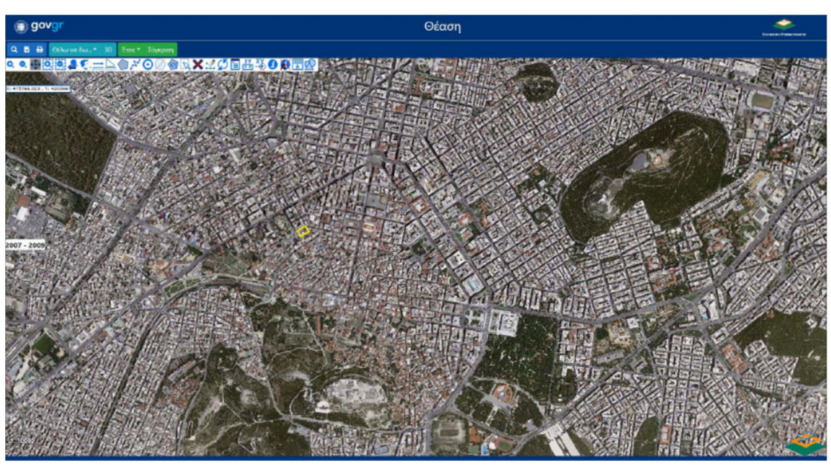

(a)

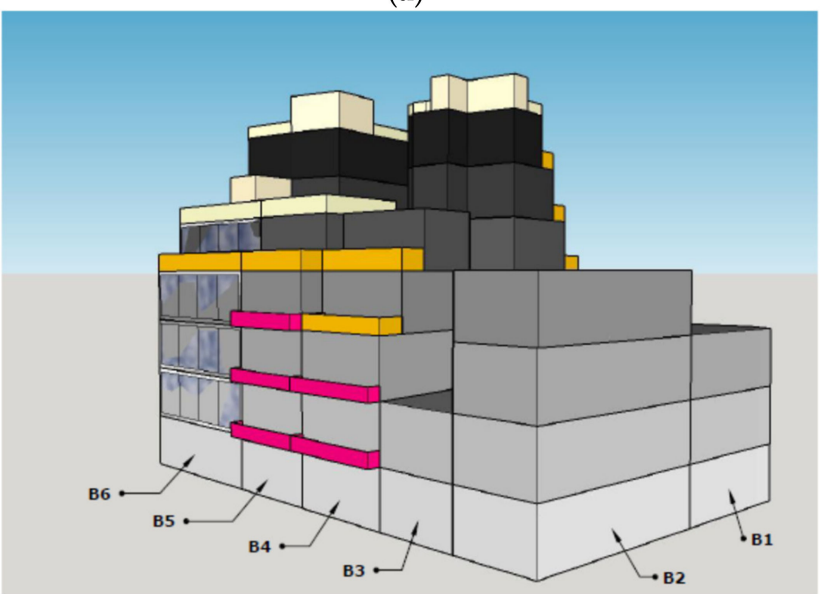

(c)

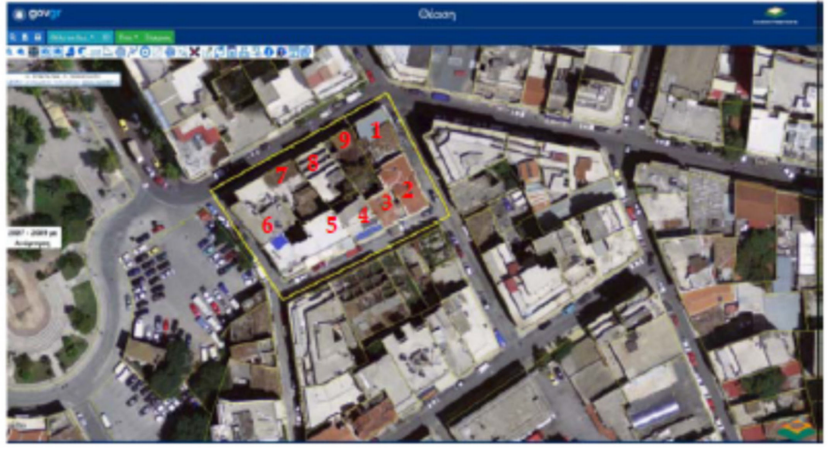

(b)

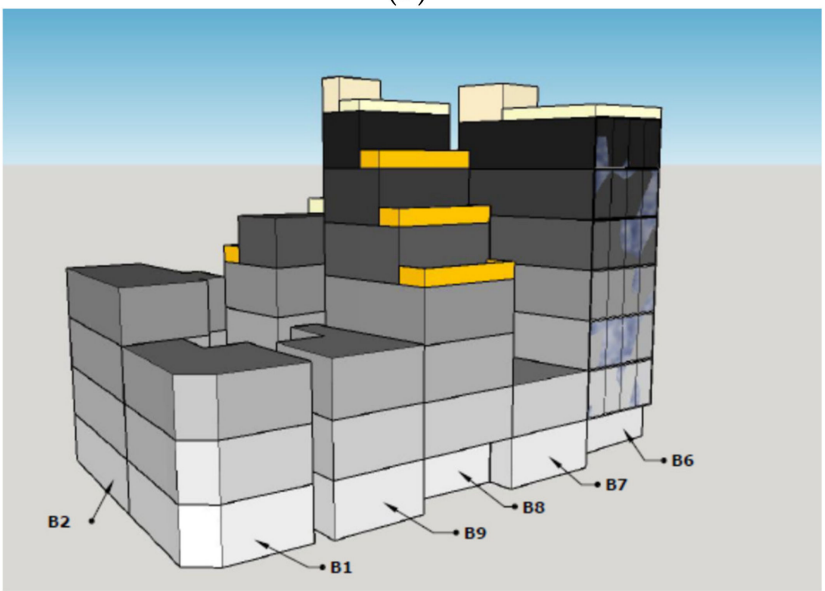

(d)

Figure 8. Athens Municipality block no. 65027 located in Athens' historic center, with plot numbering and current building volumes. (a) Building Block 65027/Study area in relation to Athens' historic triangle. (b) Building block plots numbered (by the authors). (c,d) 3D representation of plots' current building volumes.

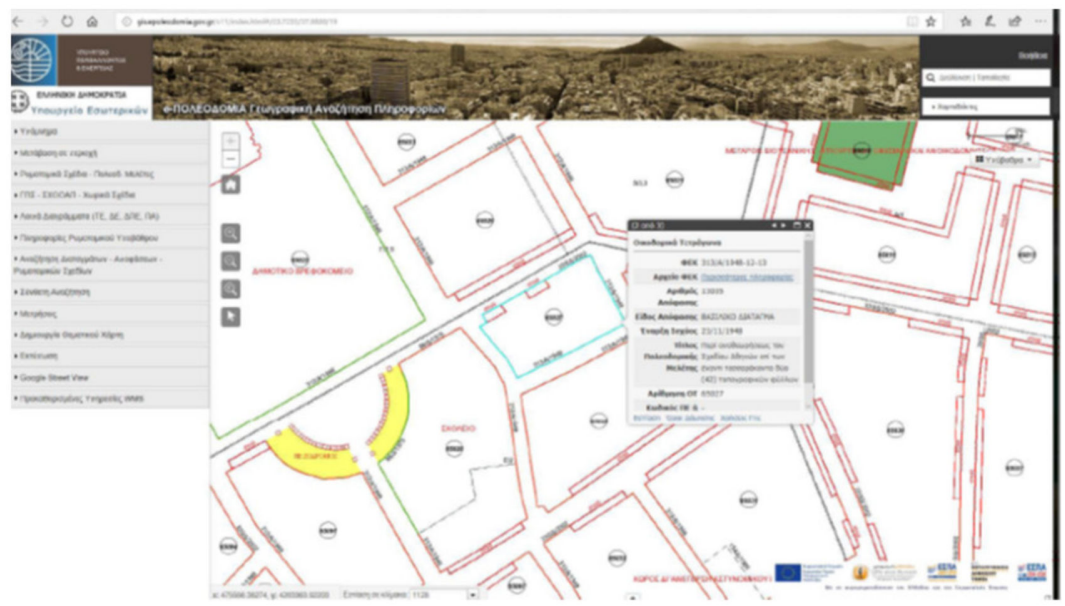

Figure 9. Block no. 65027, Athens Municipality official urban plan. (Source: e-poleodomia).

Within the boundaries of the study area, five out of the nine buildings are officially declared as listed buildings. A field survey revealed that only two listed buildings are in good condition and still in use. Two others are abandoned and collapsing, and one is not in use and in fair to poor condition. Consequently, the field survey also revealed that 
exploring existing DR and TDR options becomes imperative and is essential for cultural heritage protection, especially in the case of abandoned cultural heritage elements.

Table 3. Building characteristics, block no. 65027, Athens' historic triangle.

\begin{tabular}{cccccccc}
\hline $\begin{array}{c}\text { Plot/ } \\
\text { Building No. }\end{array}$ & Characterization & $\begin{array}{c}\text { Construction } \\
\text { Period }\end{array}$ & $\begin{array}{c}\text { Building } \\
\text { Condi- } \\
\text { tion }\end{array}$ & $\begin{array}{c}\text { Number } \\
\text { of Floors }\end{array}$ & $\begin{array}{c}\text { Constructed } \\
\text { Building } \\
\text { Factor }\end{array}$ & $\begin{array}{c}\text { Constructed } \\
\text { Building } \\
\text { Surface } \mathbf{( \mathbf { m } ^ { 2 } )}\end{array}$ & $\begin{array}{c}\text { Constructed } \\
\text { Building } \\
\text { Height }(\mathbf{m})\end{array}$ \\
\hline 1 & Listed building & $1880-1920$ & Bad & 3 & 1.70 & 258.42 & 12.5 \\
2 & Listed building & $1880-1920$ & Good & 4 & 3.90 & 592.36 & 13 \\
3 & Listed building & $1880-1920$ & Good & 2 & 1.89 & 157.78 & 7 \\
4 & - & $1960-1970$ & Average & 5 & 3.33 & 453.93 & 15 \\
5 & - & $1970-1980$ & Average & 5 & 4.76 & 558.73 & 15 \\
6 & - & $1960-1970$ & Average & 7 & 5.50 & 2202.26 & 22 \\
7 & Listed building & $1880-1920$ & Average & 2 & 1.68 & 308.16 & 10.5 \\
8 & - & $1970-1980$ & Average & 7 & 4.76 & 876.46 & 180.82 \\
9 & Listed building & $1880-1920$ & Bad & 2 & 0.92 & 12.9 \\
\hline
\end{tabular}

\section{Results}

The definitions of the active DRs for each plot, derived from comparing the actual constructed building characteristics, e.g., used building factor, total height, total built-up surface, with the characteristics conforming to the official regulations (building factor 2 and maximum height $22.75 \mathrm{~m}$, but restricted to $11 \mathrm{~m}$ in the case of listed buildings) are presented in Table 4.

Four out of five listed buildings, nos. 1, 3, 7 and 9, allow no construction and existing and exploitable DRs relate to total permissible built-up surface or the permissible number of floors; thus, DRs are "negative" and are transferable. The paradox of retaining DRs in respect of building surfaces but with no remaining DRs in respect of maximum height or number of floors is due to the construction techniques of the late 1800s and early 1900s, where floor height was over four meters. Plots that have constructed buildings before the enactment of the protective framework on cultural heritage, between the early 1950s and 1998, nos. 4, 5, 6 and 8, offer "positive" and constructive DRs for their owners, as official building regulations during their licensing and construction period were more favorable (e.g., higher building factors of 3 or 4 instead of today's 2 and a higher number of floors, seven instead of today's three). This inequality between built-up surface development and evolution and today's official permitted maximum for building volume is quantitatively defined in Table 4. The development of these plots has more than double in terms of built volume (total built-up surface and height) compared to listed building plots, resulting in significant differences between constructive and no-construction DRs and existing DRs within the same block.

Table 4. Development Rights, block No 65027, Athens' historic triangle.

\begin{tabular}{|c|c|c|c|c|}
\hline $\begin{array}{c}\text { Plot/ } \\
\text { Building No. }\end{array}$ & $\begin{array}{l}\text { Constructed } \\
\text { Building Factor/ } \\
\text { Official Maximum } \\
\text { Building Factor }\end{array}$ & $\begin{array}{c}\text { Constructed Building } \\
\text { Height/ } \\
\text { Official Maximum } \\
\text { Building Height (m) }\end{array}$ & $\begin{array}{c}\text { Total Constructed } \\
\text { Building } \\
\text { Surface/ } \\
\text { Official Maximum } \\
\text { Building Surface }\left(\mathrm{m}^{2}\right)\end{array}$ & $\begin{array}{c}\text { Constructed Floors } \\
\text { Number/ } \\
\text { Official Maximum } \\
\text { Floors Number }\end{array}$ \\
\hline 1 & -0.30 & 1.5 & -46.34 & 0 \\
\hline 2 & 1.90 & 2 & 288.86 & 1 \\
\hline 3 & -0.11 & -4 & -8.88 & -1 \\
\hline 4 & 1.33 & 4 & 181.51 & 2 \\
\hline 5 & 2.76 & 4 & 324.11 & 2 \\
\hline 6 & 3.50 & 11 & 1400.86 & 4 \\
\hline 7 & -0.32 & -0.5 & -59.06 & -1 \\
\hline 8 & 2.76 & 11 & 508.42 & 4 \\
\hline 9 & -1.08 & 1.9 & -213.42 & -1 \\
\hline
\end{tabular}


The current 3D built-up surface development and the theoretical development are visualized and three-dimensionally represented so as to illustrate "positive" and "negative" DRs. In Figure 10 the three-dimensional representation and visualization of existing building volume, in gray-colors, and the official maximum permissible building volume with no height restriction, in red and orange colors, is presented. It is obvious that if all buildings were equally developed, according to the extent of the building rules, with no other restrictions, buildings that today have the privilege of a direct view to the Acropolis would not have had it.

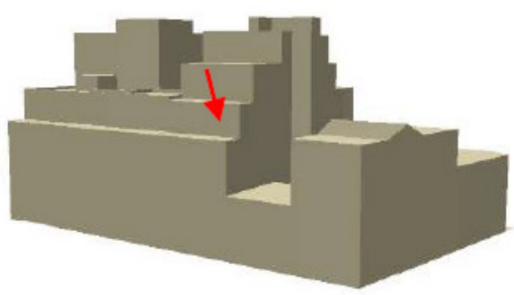

(a)

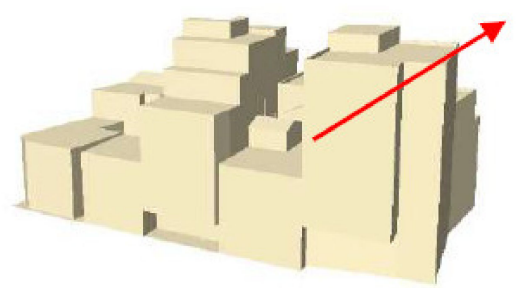

(b)

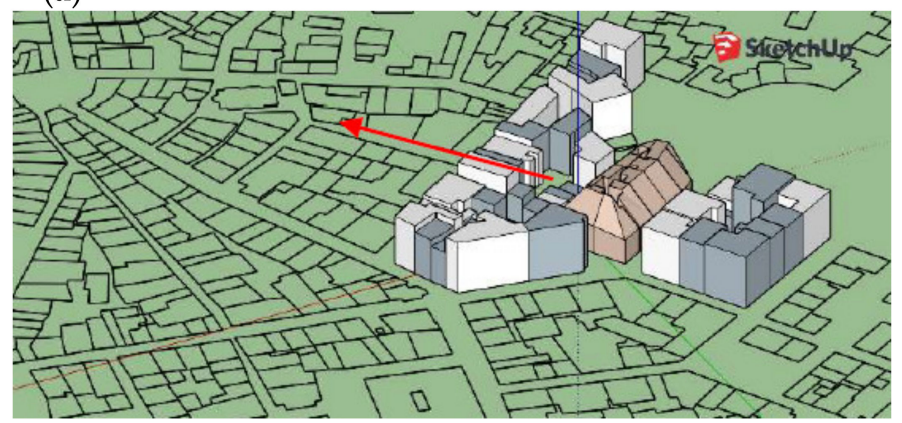

(c)

Figure 10. Cont.

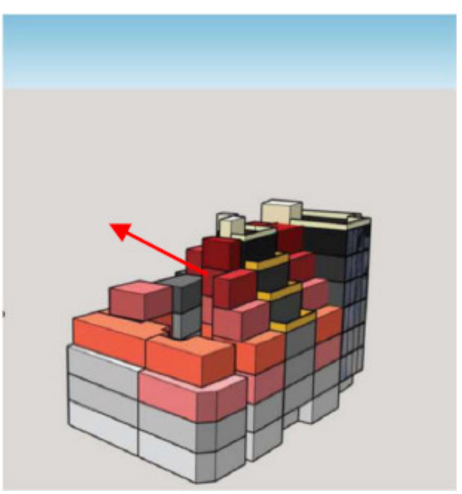

(d)

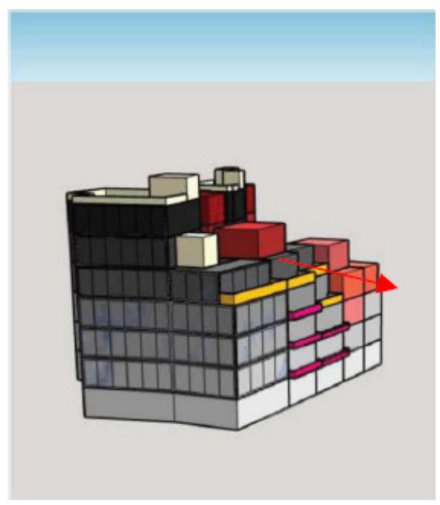

(e)

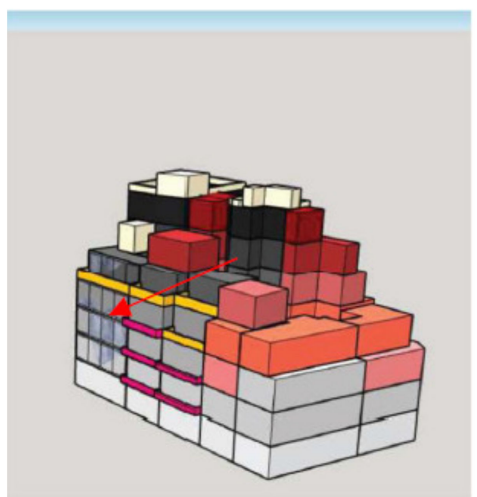

(f)

Figure 10. 3D representation of DRs and TDRs. (a) Existing buildings volume, south-north direction. (b) Existing buildings volume, east-west direction, Acropolis view. (c) Official permissible buildings volume, no height restriction, compared with neighboring buildings volume (block level), north-west/south-east direction, Acropolis view. (d) Maximum permissible buildings volume, no restrictions, north-south direction. (e) Maximum permissible buildings volume, no restrictions, east-west direction, Acropolis View. (f) Maximum permissible buildings volume, no restrictions, north-south direction, Acropolis view. Black and gray illustrates current built-up surface. Orange and red illustrates the permitted official maximum built surface that is restricted due to cultural heritage protection. Red arrow points to the Acropolis.

This diversification of built-up surfaces and building volumes, constructed/hypothetical, with no restrictions, influences 3D TDR determination in respect of their specific attributes, 
height, view and building orientation. Consequently, the reference only to unbuilt but transferable square meters (transfer of building factor) is deficient and misleading, as views of exquisite locations and monuments is an important attribute on the 3D TDR determination process. In the case study area, some buildings' floors or rooftops have direct views of the Acropolis, even though they are built in the opposite direction. On the other hand, other buildings have views only of the surrounding buildings even though they are built in the direction of the Acropolis (Figures 10 and 11).

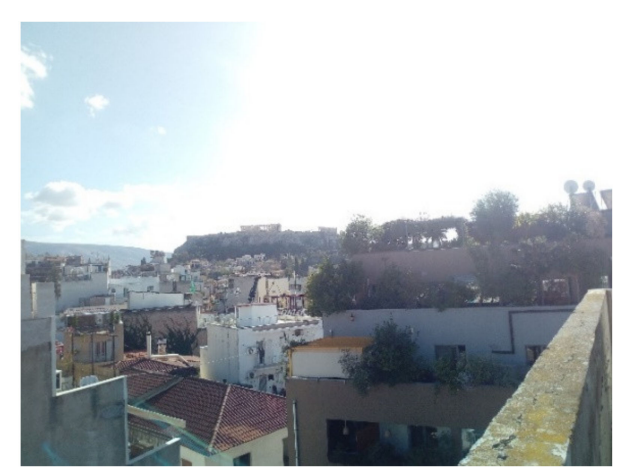

(a)

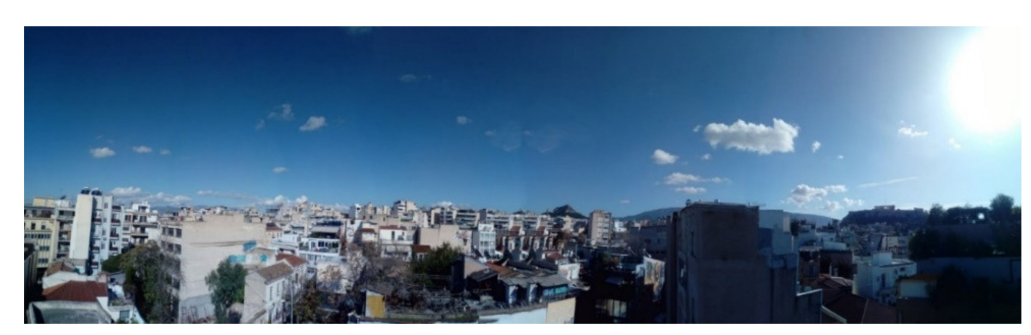

(b)

Figure 11. (a,b) Study area, roof top building view. (Author's illustration).

Thus, visibility analysis, for building or for plots DRs, is also essential. Over the last few years, spatial analysis tools have been used for the production of visibility maps, as visibility mapping is significant for cultural heritage protection and promotion [50]. For this research, visibility mapping is used to highlight the importance of the view of a monument or an exquisite location and its importance as an attribute for 3D DRs and TDRs. The visibility map for the tallest building, no. 6, is created with the use of the Arc-GIS visibility tool, and building volumes are available on the web (Figure 12). Building no. 6 has three façades, its main entrance is to the north façade, the west façade has a view toward the Piraeus Port and the north façade has a direct view of the Acropolis. Historical aerial photos of the Hellenic Military Geographical Service dated from 1919 and the 1945 Hellenic Cadastre orthophotomap, and aerials photos from 1965 and 1977 depict three-story neoclassical buildings. In the 1979 Hellenic Cadastre aerial photo the seven-story building is depicted. The direct view of the Acropolis is not and won't ever be obstructed, as neighboring or opposite buildings are less than six stories, while no further height development is feasible due to height restrictions for cultural heritage protection and listed buildings.

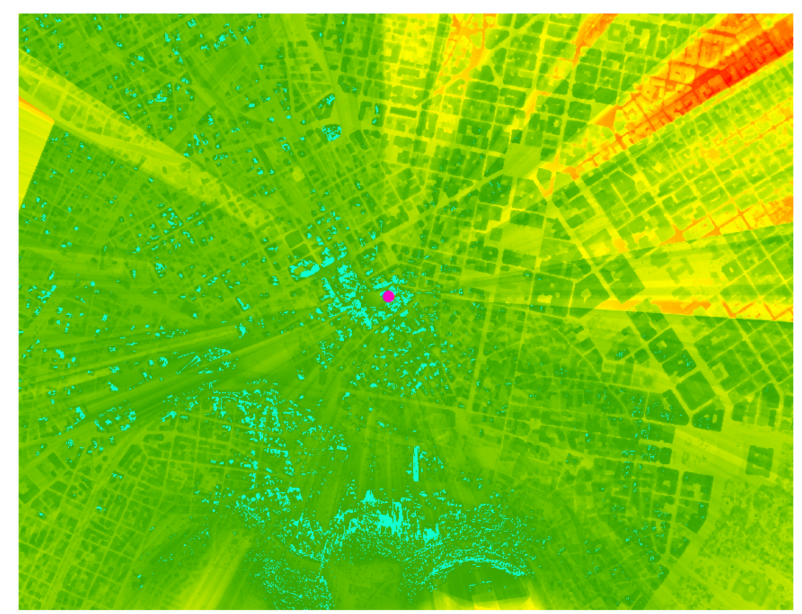

Figure 12. Visibility map from the tallest building, block no. 65027, Athens' historic triangle, northsouth direction to the Acropolis. (Author's illustration). 


\section{Discussion and Conclusions}

The results of the current research demonstrate that the protection and preservation of cultural heritage is directly related to the diversification of private property development rights, their status and overall exploitation. Especially in densely populated and central urban areas of historic cities, like Athens' historic triangle, this diversification is more intense. The legal definition of development rights and their 3D technical visualization and representation revealed positive and negative DRs. Private property owners who exploited their properties before the enactment of restrictions on construction and building activities so as to protect cultural heritage have the privilege of "positive" and constructive DRs. Simultaneously, owners of listed buildings who have lost their rights to full property exploitation are not compensated and thus have "negative" and transferable DRs. The proposed methodology also revealed that positive DRs are an important asset, as their owners can benefit most from them, e.g., by obtaining high rents due to views of important monuments like the Acropolis. Owners of negative DRs do not have adequate financial resources or funds to restore and renovate their existing properties, that is, listed buildings, resulting in wear and tear and abandonment and consequent urban environment degradation. Thus, the presented legal and 3D spatiotemporal definition of positive and negative DRs, can further facilitate and clarify the estimation of TDR cost (as this is argued in [41]). Temporal analysis of 3D DR development and correlation with past and current urban plans and cultural heritage protection legal frameworks revealed externalities in TDR definitions and costs. The state's intrusive role in cultural heritage protection resulted in imbalances in the development and exploitation of property rights. Furthermore, thorough investigation of buildings' views, especially of famous monuments and POIs, along with visibility mapping integration of 3D positive and negative DRs, can determine DRs' 3D quantitative characteristics, enhancing their legal/qualitative definition and overall TDR reliability. Following the proposed methodology, TDR is detailed legally and technically defined. Consequently, local authorities or governments are being led to incorporate TDRs in urban planning, as has been argued by other researchers, e.g., [12,42,43]. The presented methodology also provides adequate data that are necessary for the implementation of TDR programs, their monitoring and further adoption.

Author Contributions: D.-G.P. was responsible for research conceptualization, methodology, analysis and writing of the original draft. S.S., V.D., F.L., were responsible for data collection, data analysis, data curation and 3D visualization. I.K. was responsible for supervision and administration. Current research was carried out in the context of an undergraduate course "Cadastral, Urban Planning and Infrastructure Networks Systems", Department of Surveying and Geoinformatics Engineering, University of West Attica. All authors have read and agreed to the published version of the manuscript.

Funding: This research received no external funding.

Institutional Review Board Statement: Not applicable.

Informed Consent Statement: Not applicable.

Data Availability Statement: Not applicable.

Conflicts of Interest: The authors declare no conflict of interest.

\section{References}

1. Bongaarts, J. United nations department of economic and social affairs, population division world mortality report 2005. Popul. Dev. Rev. 2006, 32, 594-596.

2. UNESCO. Recommendation on the Historic Urban Landscape; UNESCO: Paris, France, 2011; Available online: https: / whc.unesco. org/uploads/activities/documents/activity-638-98.pdf (accessed on 2 September 2021).

3. UNESCO THE HUL GUIDEBOOK. Managing Heritage in Dynamic and Constantly Changing Urban Environments, a Practical Guide to UNESCO's Recomendation on the Historic Urban Land Scape. 2016. Available online: http:/ / historicurbanlandscape. com/themes/196/userfiles/download/2016/6/7/wirey5prpznidqx.pdf (accessed on 3 May 2021).

4. Alchian, A.A.; Demsetz, H. The property right paradigm. J. Econ. Hist. 1973, 33, 16-27. [CrossRef] 
5. Cai, M.; Murtazashvili, I.; Murtazashvili, J. The politics of land property rights. J. Inst. Econ. 2020, 16, 151-167. [CrossRef]

6. Feeny, D.H. The Development of Property Rights in Land: A Comparative Study; Center Discussion Paper; University of California Press: Berkeley, CA, USA, 1984.

7. Pratomo, R.A.; Samsura, D.; van der Krabben, E. Transformation of local people's property rights induced by new town development (case studies in Peri-Urban areas in Indonesia). Land 2020, 9, 236.

8. Beg, S. Digitization and Development: Property Rights Security, and Land and Labor Markets. J. Eur. Econ. Assoc. 2021. [CrossRef]

9. Frankel, J. Past, present, and future constitutional challenges to transferable development rights. Wash. L. Rev. 1999, 74, 825.

10. Daniels, T.L. The purchase of development rights: Preserving agricultural land and open space. J. Am. Plan. Assoc. 1991, 57, 421-431. [CrossRef]

11. Rose, J.G. A proposal for the separation and marketability of development rights as a technique to preserve open space. J. Urb. L. 1973, 51, 461.

12. Bengston, D.N.; Fletcher, J.O.; Nelson, K.C. Public policies for managing urban growth and protecting open space: Policy instruments and lessons learned in the United States. Landsc. Urban Plan. 2004, 69, 271-286.

13. Lee, S.; Feiock, R.C. The Role of Local Governments in Open Space Preservation and Land Acquisition in Florida. In Growth Management and Public Land Acquisition: Balancing Conservation and Development; Routledge: London, UK, 2016 ; p. 143.

14. Micelli, E. Development rights markets to manage urban plans in Italy. Urban Stud. 2002, 39, 141-154. [CrossRef]

15. Town and Country Planning (Scotland) Act, CH. 53. HMSO. 1947. Available online: https://www.legislation.gov.uk/ukpga/19 47/53/pdfs/ukpga_19470053_en.pdf (accessed on 16 August 2021).

16. Lloyd, G. Transferable Density in Connection with Zoning; Techical Bulletin 40; Urban Land Institute: Washington, DC, USA, 1961.

17. Richards, D.A. Development Rights Transfer in New-York-City; CT 06520; YALE LAW J CO INC 401-A YALE STATION: New Haven, CT, USA, 1972; Volume 82, pp. 338-372, ISBN 0044-0094.

18. Richards, D.A. Transferable development rights-corrective, catastrophe, or curiosity. Real Estate Law J. 1983, 12, $26-52$.

19. Costonis, J.J. The Chicago Plan: Incentive zoning and the preservation of urban landmarks. Harv. L. Rev. 1971, 85, 574. [CrossRef]

20. Costonis, J.J. The Disparity Issue: A Context for the Grand Central Terminal Decision. Harv. Law Rev. 1977, 402-426. [CrossRef]

21. Costonis, J.J. Development rights transfer: An exploratory essay. Yale LJ 1973, 83, 75. [CrossRef]

22. Costonis, J.J. " Fair" Compensation and the Accommodation Power: Antidotes for the Taking Impasse in Land Use Controversies. Columbia Law Rev. 1975, 75, 1021-1082. [CrossRef]

23. Pizor, P.J. Making TDR work: A study of program implementation. J. Am. Plan. Assoc. 2007, 52, 203-211. [CrossRef]

24. Chapin, T.S. Introduction: From growth controls, to comprehensive planning, to smart growth: Planning's emerging fourth wave. J. Am. Plan. Assoc. 2012, 78, 5-15. [CrossRef]

25. Colavitti, A.M.; Serra, S. The transfer of development rights as a tool for the urban growth containment: A comparison between the United States and Italy. Pap. Reg. Sci. 2018, 97, 1247-1265. [CrossRef]

26. Linkous, E.R. Transfer of development rights in theory and practice: The restructuring of TDR to incentivize development. Land Use Policy 2016, 51, 162-171. [CrossRef]

27. Shi, C.; Tang, B. Institutional change and diversity in the transfer of land development rights in China: The case of Chengdu. Urban Stud. 2020, 57, 473-489. [CrossRef]

28. Wang, H.; Lu, S.; Lu, B.; Nie, X. Overt and covert: The relationship between the transfer of land development rights and carbon emissions. Land Use Policy 2021, 108, 105665. [CrossRef]

29. Pruetz, R.; Standridge, N. What makes transfer of development rights work?: Success factors from research and practice. J. Am. Plan. Assoc. 2008, 75, 78-87. [CrossRef]

30. Chan, E.H.; Hou, J. Developing a framework to appraise the critical success factors of transfer development rights (TDRs) for built heritage conservation. Habitat Int. 2015, 46, 35-43. [CrossRef]

31. Nelson, A.C.; Pruetz, R.; Woodruff, D. The TDR Handbook: Designing and Implementing Transfer of Development Rights Programs; Island Press: Washington, WA, USA, 2013; ISBN 1-61091-159-8.

32. McConnell, V.; Walls, M. Policy monitor: US experience with transferable development rights. Rev. Environ. Econ. Policy 2009, 3, 288-303. [CrossRef]

33. Pruetz, R. (Ed.) Beyond Takings and Givings: Saving Natural Areas, Farmland and Historic Landmarks with Transfer of Development Rights and Density Transfer Charges; Arje Press: Burbank, CA, USA, 2003; ISBN 978-0965831413.

34. Johnston, R.A.; Madison, M.E. From land marks to landscapes: A review of current practices in the transfer of development rights. J. Am. Plan. Assoc. 1997, 63, 365-378. [CrossRef]

35. Robb, A.; Stocker, L.; Payne, M.; Middle, G.J. Enabling managed retreat from coastal hazard areas through property acquisition and transferable development rights: Insights from Western Australia. Urban Policy Res. 2020, 38, 230-248. [CrossRef]

36. Tian, L.; Guo, X.; Yin, W. From urban sprawl to land consolidation in suburban Shanghai under the backdrop of increasing versus decreasing balance policy: A perspective of property rights transfer. Urban Stud. 2017, 54, 878-896. [CrossRef]

37. Linkous, E.; Laurian, L.; Neely, S. Why do counties adopt transfer of development rights programs? J. Environ. Plan. Manag. 2019, 62, 2352-2374. [CrossRef]

38. Thorsnes, P.; Simons, G.P. Letting the market preserve land: The case for a market-driven transfer of development rights program. Contemp. Econ. Policy 1999, 17, 256-266. [CrossRef] 
39. Machemer, P.L.; Kaplowitz, M.D. A framework for evaluating transferable development rights programmes. J. Environ. Plan. Manag. 2002, 45, 773-795. [CrossRef]

40. Renard, V. Property rights and the'transfer of development rights': Questions of efficiency and equity. Town Plan. Rev. 2007, 78, 41-60. [CrossRef]

41. Hou, J.; Gu, D.; Shahab, S.; Chan, E.H. Implementation analysis of transfer of development rights for conserving privately owned built heritage in Hong Kong: A transactions costs perspective. Growth Chang. 2020, 51, 530-550. [CrossRef]

42. Cubukcu, K.M. The problem of fair division of surplus development rights in redevelopment of urban areas: Can the Shapley value help? Land Use Policy 2020, 91, 104320. [CrossRef]

43. BenDor, T.K.; Branham, J.; Whittemore, A.; Linkous, E.; Timmerman, D. A national inventory and analysis of US transfer of development rights programs. J. Environ. Plan. Manag. 2021, 1-21. [CrossRef]

44. Petrakos, V. The Beginning of Greek Archeology and the Foundation of Athens Archeologicla Society; Athens Archeological Society: Athens, Greece, 2004; ISBN 960-8145-44-9.

45. Official Government Gazette of the Hellenic Republic. Law on Antiquities; Official Government Gazette of the Hellenic Republic: Athens, Greece, 1899.

46. Official Government Gazette of the Hellenic Republic. On Amendments and Additions to 1899 Law on Antiquities; Official Government Gazette of the Hellenic Republic: Athens, Greece, 1932.

47. Official Government Gazette of the Hellenic Republic. Law on the State's Monuments Restoration Service; Official Government Gazette of the Hellenic Republic: Athens, Greece, 1943.

48. Official Government Gazette of the Hellenic Republic. Law on the Protection of Buildings and Art Works Created after 1830; Official Government Gazette of the Hellenic Republic: Athens, Greece, 1950.

49. Perperidou, D.-G. Spatial Planning in Greece: From the Past to the Economic Crisis \& the Future. In Proceedings of the FIG E-Working Week Smart Surveyors for Land and Water Management-Challenges in a New Reality, Amsterdam, The Netherlands, 20-25 June 2021; Available online: https: / / www.fig.net/resources/proceedings/fig_proceedings/fig2021/papers/ts08.4/TS08. 4_perperidou_11177.pdf (accessed on 1 September 2021).

50. Hellenic Parliament. Hellenic Parliament Report on the Draft Act for Antiquities and Overall Cultural Heritage Protection; Hellenic Parliament: Athens, Greece, 2002.

51. Xatzivasileiou, E. Political Course: Expression of the need for "moving forward". In Tzannis Tzannetakis, from Conssiousness to Action; Delivorias-Evanthis Xatzivasileiou, E., Ed.; Ekdoseis Polis: Athens, Greece, 2017.

52. Official Government Gazette of the Hellenic Republic. Law No 622 on the Revenues for Building Permint Approval and Other Provisions; Official Government Gazette of the Hellenic Republic: Athens, Greece, 1977.

53. Official Government Gazette of the Hellenic Republic. Law 3028 on Antiquities and Cultural Heritage Protection; Official Government Gazette of the Hellenic Republic: Athens, Greece, 2003.

54. Official Government Gazette of the Hellenic Republic. Law 880 on Maximum Building Factor Definition and Other Urban Planning Provisions; Official Government Gazette of the Hellenic Republic: Athens, Greece, 1979.

55. Council of State Decision 1310; Council of State: Athens, Greece, 1993.

56. Council of State Decision 1073; Council of State: Athens, Greece, 1994.

57. Official Government Gazette of the Hellenic Republic. Law 2300 on Tranfer of Building Factor and Other Provisions; Official Government Gazette of the Hellenic Republic: Athens, Greece, 1995.

58. Council of State Decision 2299; Council of State: Athens, Greece, 1996.

59. Council of State Decision 4572; Council of State: Athens, Greece, 1996.

60. Council of State Decision 6070; Council of State: Athens, Greece, 1996.

61. Official Government Gazette of the Hellenic Republic. Law 3044 on Tranfer of Building Factor; Official Government Gazette of the Hellenic Republic: Athens, Greece, 2002.

62. Council of State Decision 2366; Council of State: Athens, Greece, 2007.

63. Official Government Gazette of the Hellenic Republic. Law 4495 on Built Environmnet Protection and Other Provisions; Official Government Gazette of the Hellenic Republic: Athens, Greece, 2017.

64. Official Government Gazette of the Hellenic Republic. Law 4759 on Spatial and Urban Planning Modernization and Other Provisions; Official Government Gazette of the Hellenic Republic: Athens, Greece, 2020.

65. Bélanger, P. Altitudes of urbanization. Tunn. Undergr. Space Technol. 2016, 100, 5-7. [CrossRef]

66. Paulsson, J. Reasons for introducing 3D property in a legal system-Illustrated by the Swedish case. Land Use Policy 2013, 33, 195-203. [CrossRef]

67. Paasch, J.M.; Paulsson, J. 3D Property Research from a Legal Perspective Revisited. Land 2021, 10, 494. [CrossRef]

68. Perperidou, D.-G.; Moschopoulos, G.; Sigizis, K.; Ampatzidis, D. Greece's Laws on Properties and the Third Dimension: A Comparative Analysis; FIG: Amsterdam, The Netherlands, 2021; p. 13. Available online: https://fig.net/resources/proceedings/fig proceedings/fig2021/papers/ws_03.3/WS_03.3_perperidou_moschopoulos_et_al_11186.pdf (accessed on 1 September 2021).

69. Griffith-Charles, C.; Sutherland, M. 3D Cadastres for Complex Extra-Legal and Informal Situations. In Proceedings of the 6th International FIG Workshop on 3D Cadastres, Delft, The Netherlands, 2-4 October 2018; FIG: Copenhagen, Denmark, 2021; pp. 357-370. 
70. Perperidou, D. Spatial and Descriptive Documentation of Land Parcels in Hellenic Cadastre: The Case of Mati and Kokkino Limanaki Areas; FIG: Amsterdam, The Netherlands, 2020; Available online: https://www.fig.net/resources/proceedings/fig_proceedings / fig202 0/papers/ts03h/TS03H_perperidou_10387.pdf (accessed on 4 March 2021).

71. Theodoropoulos, P.; Perperidou, D.-G. Transfer of Development Rights E Cultural Heritage Protection: The Case of 3D Urban Implementation Plans; Department of Planning and Regional Development, University of Thessaly: Volos, Greece, 2019; pp. 441-452.

72. Biris, K.H. Athens from 19th to 20th Century [In Greek: Ai Athinai, apo ton 180 Ston 19o Aiona], 5th ed.; Melissa Publishing House: Athens, Greece, 2005; ISBN 960-204-026-2. 